Article

\title{
Political Journalists and Their Social Media Audiences: New Power Relations
}

\author{
Axel Bruns ${ }^{1, *}$ and Christian Nuernbergk ${ }^{2}$ \\ ${ }^{1}$ Digital Media Research Centre, Queensland University of Technology, Brisbane, QLD 4001, Australia; \\ E-Mail: a.bruns@qut.edu.au \\ ${ }^{2}$ Media Studies, Trier University, 54286 Trier, Germany; E-Mail: nuernbergk@uni-trier.de \\ * Corresponding author
}

Submitted: 30 September 2018 | Accepted: 15 January 2019 | Published: 21 March 2019

\begin{abstract}
Social media use is now commonplace across journalism, in spite of lingering unease about the impact the networked, real-time logic of leading social media platforms may have on the quality of journalistic coverage. As a result, distinct journalistic voices are forced to compete more directly with experts, commentators, sources, and other stakeholders within the same space. Such shifting power relations may be observed also in the interactions between political journalists and their audiences on major social media platforms. This article therefore pursues a cross-national comparison of interactions between political journalists and their audiences on Twitter in Germany and Australia, documenting how the differences in the status of Twitter in each country's media environment manifest in activities and network interactions. In each country, we observed Twitter interactions around the national parliamentary press corps (the Bundespressekonferenz and the Federal Press Gallery), gathering all public tweets by and directed at the journalists' accounts during 2017. We examine overall activity and engagement patterns and highlight significant differences between the two national groups; and we conduct further network analysis to examine the prevalent connections and engagement between press corps journalists themselves, and between journalists, their audiences, and other interlocutors on Twitter. New structures of information flows, of influence, and thus ultimately of power relations become evident in this analysis.
\end{abstract}

\section{Keywords}

Australia; interactions; Germany; network analysis; political journalism; press corps; social media; Twitter

Issue

This article is part of the issue "Journalism and Social Media: Redistribution of Power?", edited by Marcel Broersma and Scott Eldridge II (University of Groningen, The Netherlands).

(C) 2019 by the authors; licensee Cogitatio (Lisbon, Portugal). This article is licensed under a Creative Commons Attribution 4.0 International License (CC BY).

\section{Introduction}

In spite of considerable reluctance and even hostility towards social media at earlier stages, journalists have now broadly accepted tools such as Facebook and especially Twitter as part of their overall professional toolkit. Journalists have recognised the utility of social media especially as sources of live updates during breaking news situations (Bruno, 2011); many subjects of journalists' stories are present on and even notorious for their usage of social media (Ausserhofer \& Maireder, 2013); journalists have been actively encouraged to develop a social media presence by the social media 'evangelists' employed by their organisations (Tenore, 2010); and at a time of considerable industrial change and employment precarity, journalists also derive career benefits from developing a strong "personal brand" independent of the news organisation (Molyneux \& Holton, 2015).

This gradual embrace of social media as platforms for monitoring, sourcing, disseminating, and discussing news stories also recognises broader, generational transformations: as the Reuters Institute Digital News Report 
2017 shows, the use of print and broadcast news has declined precipitously in many nations, and especially younger audiences are now predominantly using online and social media as their main news sources (Newman, Fletcher, Kalogeropoulos, Levy, \& Nielsen, 2017, p. 11). In becoming more active on social media, therefore, journalists are simply going where their audiences and potential sources are.

But in doing so they also expose themselves to new media logics: "with social media, journalism and audiences meet on uncommon ground" (Loosen \& Schmidt, 2016, p. 7). Social media platforms are general-purpose spaces operated by third parties, rather than controlled by news outlets in the way that masthead websites (including the comment functionality on these sites) had been. Journalists, sources, audiences, and other stakeholders therefore now encounter each other in a "third space" (Wright, Graham, \& Jackson, 2016), and must adapt to the rules of that space. But such rules are co-evolved between platform providers and users, influenced by the platforms' communicative affordances, the providers' explicit governance decisions, and the user community's implicit conventions. This has the potential to fundamentally affect and alter the power relations between the various participants in news and journalism.

In contrast to the gradual normalisation of previous medial disruptions-newsprint digitalisation, 24-hour news channels, blogging (Singer, 2005)-into standard journalistic practice, the tendency now may thus be not for social media to be adapted into established news production practices and logics, but rather for news and journalism to be normalised into social media, and subsumed by social media logics (Bruns, 2018). The pull of social media as spaces where news is disseminated and discussed may exceed the power of established journalistic practices and structures to resist this incorporation. In particular, the greater personal and interpersonal focus of leading social media spaces may weaken the boundaries of journalistic institutions.

Engagement through social media exposes the journalist as individual, even more than personality-driven formats like radio and television news. Hedman (2016, p. 11) asks, therefore, "does journalism now include not only the content but also the journalist herself?" Some journalists will regard this shift as liberating and empowering, but it may also have unintended and negative consequences: the greater public spotlight on the individual discourages journalists who are more likely to be subjected to personal attacks on social media-including women, as well as those representing minorities defined by their ethnic, religious, or sexual identity-and may perpetuate the overrepresentation of white, male, cisgendered staff in news organisations.

Following this increasing emphasis on the individual news practitioner, it therefore becomes necessary to closely analyse how journalistic practices and processes transform with the transition to social media as central platforms. Such transformations will vary as they unfold across different national and institutional contexts, in diverse thematic newsbeats, and over extended timeframes. This article addresses this challenge by observing the posting and interaction patterns of leading political journalists on Twitter in Germany and Australia throughout 2017. We focus on the national parliamentary press corps (the Bundespressekonferenz and the Federal Press Gallery), examining all public tweets by and directed at the journalists' accounts.

We follow two broad analytical approaches. First, we assess overall activity and engagement patterns for the two press corps: we develop key metrics that evaluate the journalists' own usage strategies, and highlight significant differences between the two national groups. We also assess how Twitter users approach and respond to the content provided by press corps journalists. Second, we conduct further network analyses to examine the prevalent interactions between press corps journalists themselves, and between journalists, their audiences, and other interlocutors. In combination, the quantitative data indicate starkly differing levels of social media takeup between political journalists and their audiences in Germany and Australia, as well as within the press corps in each country, while the network analyses provide possible explanations for these patterns and point variously to the persistence of old or emergence of new power relations between interactants.

\section{Political Journalism and Social Media}

Political journalism has been described as "'the most sacred part' of journalism" (Neveu, 2002, p. 23). Its prestigious position as an intermediary between the people and the political elite, generally producing highly visible news, comes with substantial societal and democratic expectations. Especially at the national level, leading political journalists often enjoy considerable influence and recognition both amongst the general public and in their own profession, yet the political newsbeat is also one of the most intensely critiqued and criticised (Albæk, van Dalen, Jebril, \& de Vreese, 2014, p. 34). Notably, such influence also extends to communicative choices: for example, the successful use of Twitter by key political journalists during a 2009 leadership crisis in Australia led to widespread take-up of the then still novel medium amongst journalists and their followers, well beyond the politics beat itself (Posetti, 2010).

But in a multimodal and hybrid environment, the interconnection between journalists, politicians, and the public has become more complex (Chadwick, 2013): journalists and traditional news organisations can no longer claim a monopoly on public information, and have to deal with political sources that have themselves become media producers. In politics, the negotiation of meanings increasingly takes place in public, and social mediawhere politicians, journalists, and activists are present and observe each other contemporaneously-play an important role here (Ekman \& Widholm, 2015). Encounters 
between political journalists and politicians during routine periods remain especially under-researched (Albæk et al., 2014, p. 53).

While several studies examine the social media activities of politicians or journalists in general, few studies specifically survey political journalists on this issue or directly analyse concrete interactions between political journalists and politicians. Dutch research suggests that journalists on Twitter form tightly-knit networks: Vergeer (2015, p. 283) detected a strongly connected network of follower-followee relations between Dutch journalists; Verweij (2012, p. 687) found a highly connected network between Dutch politicians and political journalists. From surveys, Rogstad (2014) showed that Norwegian political journalists tend to use Twitter in an almost non-private manner: although journalists engage with social media, they exhibit differences in their self-promotion and expression of personal opinions. Similarly, using content analysis, Nuernbergk (2016) found that German political journalists very rarely tweeted messages of personal relevance: they mainly interacted with other journalists and politicians via @mentions in their tweets. Further exploring homophily, Hanusch and Nölleke (2018) report that Australian journalists interact in a journalism-centred bubble especially in their @mentions, while retweets show slightly more diversity. Patterns of homophily exist across different beats, especially amongst sports journalists and political journalists; due to gender or geographic proximity; and also between journalists at the same outlet.

The interactions of political journalists on Twitter also reveal some of the dynamics of an agendabuilding and agenda-setting process that previously had been considerably less public (Parmelee, 2014; Russell, Hendricks, Choi, \& Stephens, 2015). Journalists as well as politicians, experts, activists, and other stakeholders in policy-making processes interact to request information, make statements, correct perceived misrepresentations, or even engage in more phatic social communication. The more public nature of such exchanges can enable journalists to force politicians into providing a response they would not have offered in a non-public, one-on-one context; however, the ability to make public statements through social media has also enabled some politicians to withdraw altogether from the more intensive "negotiation-through-conversation" that is possible in interview contexts (Broersma \& Graham, 2013, p. 449). In this article, we therefore also explore the network structure of leading political journalists' Twitter interactions, and examine what other accounts they predominantly engage with.

We compare Australia and Germany because the two countries differ markedly in the structure of their news media industries, as well as in the professional and popular take-up of Twitter and other social media platforms for news consumption, political debate, and other purposes. Demographic factors may play a role here: Australians are younger on average than Germans, and this holds true also for the journalism industry. According to Worlds of Journalism, German journalists $(M=46)$ are nearly ten years older on average than their Australian colleagues ( $M=37$ ) (Hanusch, 2013; Steindl, Laurerer, \& Hanitzsch, 2017). This may explain Australia's greater adoption of social media at least in part.

Further, the Australian news media landscape is notoriously concentrated, with a few domestic media companies (News Corporation, Fairfax, and the public broadcaster $A B C$ ) dominating online marketshare (Young, 2010). The German news market is considerably more diverse, and features strong public service media alongside a wide range of national and regional print and broadcast offerings (Thomaß \& Horz, 2018). Germany can be considered a "Democratic Corporatist" system because of its strong public service media, journalistic professionalisation, and (still) high press market reach (Brüggemann, Engesser, Büchel, Humprecht, \& Castro, 2014; Hallin \& Mancini, 2004). Australia is a more complicated case: its media system is an "outrider" amongst the Liberal group. Compared to the UK, the Australian media system is less regulated; compared to the US, it lacks a tradition of "widespread self-regulatory professionalism" (Jones \& Pusey, 2010, p. 465). Here, the power of journalistic norms might be limited, and Australian journalists may be more ready to experiment with new tools and platforms.

Perhaps as a result of their rather limited choice of news outlets, Australians have been comparatively enthusiastic adopters of social media for news and other purposes, while Germans have remained significantly more reserved. According to the Digital News Report, only $31 \%$ of Germans use social media as a source of news; this compares to $52 \%$ in Australia, where social media have overtaken print sources (Newman, Fletcher, Kalogeropoulos, Levy, \& Nielsen, 2018, pp. 81, 127). Of those who had used social media for news in the last week, $11 \%$ of the German respondents and $18 \%$ of the Australians were following a journalist via social media (Hölig \& Hasebrink, 2018, p. 47; Park, Fisher, Fuller, \& Lee, 2018, p. 99). These figures suggest that, on average, Australian journalists should be likely to have more followers and receive more engagement than their German colleagues.

We expect these differences to manifest in the uses of Twitter by, and the audience engagement with, journalists in the respective parliamentary press corps. We specifically chose not to examine press corps in countries such as the U.S. because journalists' social media activities there are already comparatively overrepresented in the scholarly literature, even though the idiosyncratic media and political system of the U.S. does not resemble any structures found in other democratic nations (Zuiderveen Borgesius et al., 2016, p. 11). Arguably, the Australian and German contexts are more representative of a wide range of other political and media environments, and our findings may therefore also translate more directly to other nations. 


\section{Methods and Data}

This article builds on a comprehensive dataset of tweets by and directed at these journalists during 2017. We accessed the official registers of journalists accredited to the Australian Federal Press Gallery and German Bundespressekonferenz (2016/2017 period) to retrieve an upto-date list of current members. We then searched Twitter for the journalists' profiles, if available, and manually reviewed these accounts in order to ensure that we had found the journalists' official profiles rather than those of namesakes, impostors, or parody accounts. For the 303 accredited Press Gallery members in Australia at the time, we identified 189 Twitter accounts (62\%); for the 825 members of the Bundespressekonferenz, we identified 461 accounts (56\%). This indicates a broadly comparable adoption rate amongst leading political journalists in Australia and Germany, in spite of differences in the size and diversity of the press corps and the general use of Twitter and other platforms in the two countries. Of these accounts, 115 (61\%) Australian and 55 (12\%) German accounts had received official verification (the 'blue tick') from Twitter; we see this as demonstrating the relatively greater attention paid to their Twitter presences by Australian press corps journalists and news outlets.

For these accounts, we used Twitter's Application Programming Interface (API) to retrieve their public profile information, and the Twitter Capture and Analysis Toolkit (TCAT; Borra \& Rieder, 2014) to capture both any public tweets originating from these accounts, and any public tweets by other Twitter accounts that @mentioned or retweeted them. Data gathering commenced in 2016, and continues at the time of writing.

For the present article, we selected the tweets posted by and directed at press corps accounts in each country during 2017. We do so in order to observe longerterm patterns in tweeting activity around these journalists, beyond short-term events, debates, and crises. This does not mean that our data are unaffected by such events, of course: inter alia, 2017 included the inauguration and subsequent actions of U.S. President Donald Trump; continuing negotiations about the United Kingdom's exit from the European Union; a controversial G20 summit in Hamburg (involving Trump as well as the German and Australian leaders); continuing political leadership speculation in Australia; the German federal election on 24 September; and an Australian postal referendum on the legalisation of same-sex marriage in September to November 2017. Such events will inevitably affect social media engagement patterns around journalists, but over the course of the year our data show how journalists and their audiences use Twitter to address a broad range of political issues during this turbulent phase in national and international politics.

\section{Findings}

\subsection{Activity by Journalists}

We begin our analysis with a number of descriptive statistics (Table 1, Appendix). First, of the press corps accounts we identified, 182 (96\%) Australian and 400 (87\%) German accounts actively tweeted during 2017. The total volume of tweets generated by each group is broadly comparable, but given their different sizes this indicates a considerably more active use of Twitter by Australian political journalists: on average, they posted just over four tweets per day in 2017, while German journalists managed only 1.7 tweets. However, in each country a smaller group of particularly enthusiastic adopters is responsible for much of this tweeting: in Germany, the top decile of the 40 most active accounts posted some $62 \%$ of all tweets (5.3 tweets per day); in Australia, the top decile of 18 accounts contributed $50 \%$ of all tweets (19.7 tweets per day). The most active Australian accounts thus provide a steady running commentary about political events, while their German counterparts remain considerably more restrained.

Australian press corps journalists have also attracted far more followers. Unsurprisingly, however, the median figures indicate that such attention is again very unevenly distributed: a handful of journalists command far greater audiences than their colleagues. In each country, the most active tweeters also attract larger numbers of followers; however, activity levels are not the only or even the main criterion as Twitter users choose which political journalists to follow: the most followed journalists in Australia and Germany account for only $29 \%$ or $39 \%$ of all tweets, respectively, but have considerably larger audiences on Twitter than their more active colleagues. This discrepancy may be partly explained by personal or institutional brand recognition.

Across the entire press corps, in both countries, the median number of followees for journalists' accounts is roughly half the median number of followers; overall, this would mean there is a one-in-two chance that a user may be followed back by a journalist. However, these patterns break down for the most active and the most followed press gallery accounts: here, the chance of being followed back becomes considerably more remote.

In tweets, users can @mention or retweet other accounts, or make an original statement without reference to any other participants. The tweets by Australian press corps journalists are relatively evenly distributed across these three tweet types (Table 2, Appendix). This does not vary significantly for the most active accounts. In Germany, however, there is a substantially greater focus on interactive tweet types: only $23 \%$ of all tweets by Bundespressekonferenz journalists are original tweets (again, this is stable across the deciles). This may indicate a different understanding of the role of Twitter: while in Australia, Twitter and other social media are now clearly established as platforms for the dissemination of original, 
first-hand information, in Germany they may still constitute secondary media for discussing and sharing the news rather than posting genuine news updates.

Collectively, each account population @mentions and retweets nearly 30,000 unique accounts. Again, the top decile of German journalists is chiefly responsible for this diversity of interlocutors. In Australia, the top decile is slightly more concentrated on a core of frequent interlocutors. More generally, as Australian press corps journalists are considerably more active overall, this also manifests in the volume of @mentions and retweets they post through the year: their number of such posts per account is considerably higher.

\subsection{Activity Directed at Journalists}

These tweeting activities by the German and Australian press corps are reciprocated in divergent ways by the broader Twitter audience. In total, the Australian journalists received some 1.9 million retweets and @mentions from 231,496 unique accounts during 2017; German journalists were @mentioned and retweeted only 714,206 times by 116,790 accounts (Table 3, Appendix). In each case, roughly one quarter of these interactions were retweets, and the remainder @mentions. Further, $48 \%$ of all Twitter accounts engaging with the German press corps retweeted at least one of their tweets; in Australia, only $36 \%$ of all accounts did so. Rather than simply passing on these leading political journalists' posts, therefore, Twitter users predominantly choose to talk to, at, or about them; in Australia, the focus on discourse over amplification is especially strong.

The significant variation in overall volume may have several explanations: first, while the Australian (social media) population is considerably smaller than the German, the international Anglophone community is substantially larger than that of German-speakers, and Australian journalists may therefore also have found a global audience for their accounts. However, as national politics may not attract substantial international audiences; it is equally possible that the significantly greater engagement with Australian journalists' accounts stems from the fundamentally different importance of Twitter-and social media more generally-as a source of news for Australian users (Newman et al., 2018).

Consequently, the mean and median metrics per journalistic account also vary substantially. On average, a German press corps journalist can expect some 548 retweets and 1,411@mentions of the course of a year; their Australian counterpart will be retweeted 2,750 and @mentioned 8,348 times. Indeed, the averages for ordinary Australian political journalists are broadly comparable with those for the most active German press corps members.

However, in Germany $59 \%$ of all tweets from other users are directed at the top decile of most active journalists, and $63 \%$ of mentioning users engage especially with these leading accounts; in Australia, general user attention is more broadly distributed. This may serve to increase the diversity of public debate about domestic politics, as the discussion involves a wider range of journalistic voices: while engagement around the most active Australian press corps accounts is clearly very intense, it represents less than half of all engagement with press corps accounts.

\subsection{Activity between Journalists}

As noted, increased social media use in journalism may lead to a significant reshaping of power relationships between journalists, politicians, other stakeholders, and audiences. Social media engagement reduces the power of institutional authority, and places journalistic news reporting and discussion practices at risk of being subsumed into social media logics. This makes it especially important to examine whether-even within less controllable social media environments-journalists talk mainly amongst themselves, or allow other stakeholders to enter the conversation. Where journalists engage with each other, we may also explore whether such interactions follow institutional lines (colleague-to-colleague) or involve other members of the press corps (indicating a domestic equivalent of the notorious 'inside-thebeltway' bubble in U.S. politics).

We examine this, first, by analysing the mentions between the press corps accounts in our study. We acknowledge that the perspective this enables is necessarily somewhat limited: the journalists may also interact with journalists who are not themselves members of the press corps, and thus still remain within a broader professional 'bubble' rather than genuinely broadening their discussions to include a more diverse range of participants. Our observations of 'insider' conversations between press corps journalists on Twitter are therefore likely to systematically underestimate the extent of journalists' inward focus, but they nonetheless remain indicative of broader trends.

We focus here on @mentions rather than retweets: we expect the latter to primarily facilitate the endorsement and promotion of news stories published by the journalists' own outlets, as well as-to an extent that varies across news organisations, as shown in Bruns, Nuernbergk, and Schapals (2018)-by competitors, while the former constitute the primary vehicle of genuine conversation and debate on Twitter.

Of the more than 110,000 @mentions posted by each press corps during this year, some 13,358 @mentions by the German journalists (12\%) were directed at fellow press corps members (Table 4, Appendix); for Australia, that number increases to 22,296 @mentions (22\%). These percentages remain stable for the most active and most followed top deciles amongst each press corps. This suggests that members of the Australian Press Gallery are twice as inwardly focussed in their @mentioning: 'inside-the-beltway' tendencies amongst this group are more prominent in Australia than they are in Germany. 
The relatively small percentages of in-group @mentions also indicate that these professional bubbles remain highly permeable, however. Countering the myth of a hermetically sealed "filter bubble" (Pariser, 2011), both press corps do engage with outside accounts substantially more than they do amongst themselves; such engagement could still be exclusive and lacking in diversity if it is directed mainly at politicians and other notable news actors rather than at ordinary Twitter users, of course, but on the evidence so far it does not give rise to an entirely homophilous network that is populated only by journalistic insiders.

In this context, it is also notable that engagement even within the press corps themselves is comparatively diverse: each one of the 162 Australian @mentioning journalists also received at least one @mention during 2017; in Germany, the 319 @mentioning journalists @mentioned 331 unique press corps members. Although the number of @mentions they received will vary considerably, few were left entirely unmentioned over the course of the year, therefore.

An exhaustive categorisation of the roughly 20,000 unique accounts @mentioned by each of the press corps during 2017 was well beyond the scope of the present study. However, we further explored the diversity of @mention targets in each country by examining the most consistently @mentioned accounts. We selected those accounts that were @mentioned by at least three different press corps journalists, and at least ten times in total by those three or more journalists. This left 170 $@$ mentioned accounts for the German press corps and 223 for their Australian colleagues (Table 5, Appendix). Two coders sighted the profile information and recent tweeting history for each account, and assigned an actor type ${ }^{1}$.

This exercise again revealed a somewhat greater insider focus amongst Australian press corps journalists: $48 \%$ of their most frequently @mentioned accounts belonged to journalists inside and outside the Press Gallery, and another $14 \%$ were institutional accounts operated by news organisations; in Germany, $31 \%$ of the accounts belonged to journalists, and $24 \%$ to news organisations. This suggests a greater institutional rather than individual focus amongst German political journalists, and supports the picture of a less advanced use of social media for personal branding, and of more persistent institutional loyalties, while in Australia Twitter is more strongly established as a public backchannel amongst the journalistic class, and institutional news outlets are now somewhat less prominent.

Further, German press corps accounts @mention key political actors more actively than their Australian counterparts; this could also be an indication of the greater range of political interlocutors available in Germany than in Australia. Other categories of Twitter ac- counts constitute a considerably smaller subset in both countries: while the general Twitter public direct a substantial amount of tweets at press corps members, they only rarely become frequent and persistent conversation partners.

\subsection{Network Analysis}

We illustrate these patterns of interaction around press corps accounts through the final step in our analysis: the visualisation of the core interaction networks. Here, we reduce the total interaction network for each country in 2017 to those directed edges with a weight of at least 10 that originate from a journalist's account-in other words, we focus on the journalists, and on the accounts with which they chose to interact most consistently over the year. This leaves 1,352 Twitter accounts (including 213 press corps accounts, or $46 \%$ ) for the German Bundespressekonferenz, and 1,349 accounts (including 125 press corps accounts, or $66 \%$ ) for the Australian Press Gallery. Respectively, these networks contain 2,395 (Germany) and 2,918 (Australia) edges; in spite of their similar population size, therefore, the Australian network is significantly more dense.

We use the Force Atlas 2 algorithm (Jacomy, Venturini, Heymann, \& Bastian, 2014) as implemented in Gephi (Bastian, Heymann, \& Jacomy, 2009) to visualise these networks: each Twitter account is a node in the network, and each @mention an edge between two nodes. The force-directed visualisation then produces clusters amongst especially densely connected subsets of the network, and places these at greater distance from other nodes that are less closely connected. Further, we colourcode the nodes (accounts) according to the news outlet that each press corps journalist worked for, and size them to indicate the number of @mentions received over the course of the year. Using otherwise identical visualisation settings, the results document further structural differences between the German and Australian press corps networks (Figures 1 and 2). In addition to a higher network density, the Australian network also exhibits a shorter average geodesic distance between reachable pairs of nodes. On average, such shorter distances structurally enhance information flows.

The German network is characterised by a central core around a collection of frequently @mentioned nonpress corps accounts including leading domestic politicians, political parties, and news outlets (but @realdonaldtrump also features here). Most major news outlets are represented in this network by at least one of their journalists, and there is a tendency for journalist accounts to cluster according to their employers; this indicates a greater propensity to @mention in-house colleagues than external competitors. Some news outlets and their most frequent interlocutors are located further

\footnotetext{
${ }^{1}$ Possible actor types were domestic politicians/political organisations, individual journalists, news organisations, international accounts, and others (including ordinary citizens). An intercoder reliability test by the two coders on a randomly selected sample of accounts achieved satisfactory results (Krippendorf's $\alpha=0.95,62$ decisions).
} 


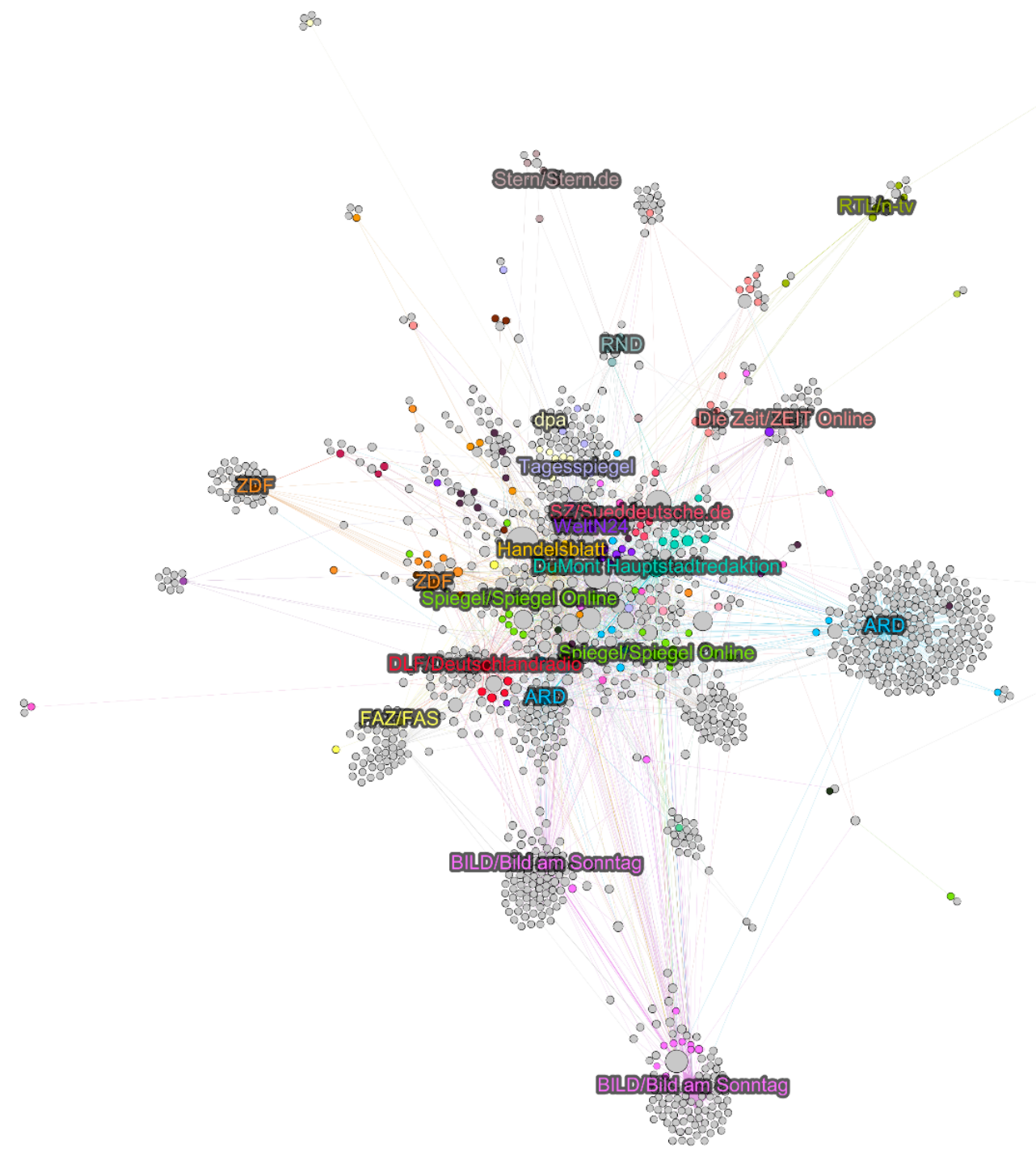

Figure 1. Bundespressekonferenz @mention network for accounts with degree >9 (2017). Network diameter: 9 (average geodesic distance: 4.147$)$. Network density: $0.001^{2}$.

from the network centre: this suggests that their press corps members engage mainly amongst themselves and with a distinct set of conversation partners outside the network core. Such groups include journalists from the tabloid Bild; commercial TV station RTL and its subsidiary $n$-tv; some but not all of the journalists working for public service network $A R D$; and many of the journalists for the weekly newspaper Zeit. Their subdivisions, especially amongst $A R D$ personnel, tend to reflect distinctions between internal units: the prime-time news team are distinct from the current affairs team, for example.

By contrast, the Australian network shows far fewer obvious subdivisions: although here, too, the accounts of journalists tend to cluster by news outlet, this does not lead to significant scissions within the overall network.
An initial assumption that the networking patterns evident here might represent the news organisations' relative ideological positioning was also not confirmed: journalists working for Rupert Murdoch's staunchly conservative News Corporation outlets are surrounded by the centrist public broadcaster $A B C$ and the broadly progressive Fairfax group. More likely, the positioning of press corps accounts in this graph simply indicates the relative prominence (at least on Twitter) of the respective news organisations, with NewsCorp, Fairfax, and $A B C$ at the centre and more minor outlets (Australian Financial Review, The Guardian, The West Australian) closer to the periphery.

This reading would again support our underlying perspective on the respective roles of Twitter in Australia and Germany. Recall that the structure of these net-

\footnotetext{
2 The network density is the proportion of all possible edges (connections between nodes) that are actually present in the graph. It ranges from 0 (no edges present) to 1 (all possible edges between all pairs of nodes present). A geodesic path, or shortest path, is a path with the minimum number of edges between two nodes in a graph. Its length is called geodesic distance. Average distance is the average geodesic distance amongst reachable pairs. The diameter measures the length of the largest geodesic between any pair of nodes in a graph.
} 


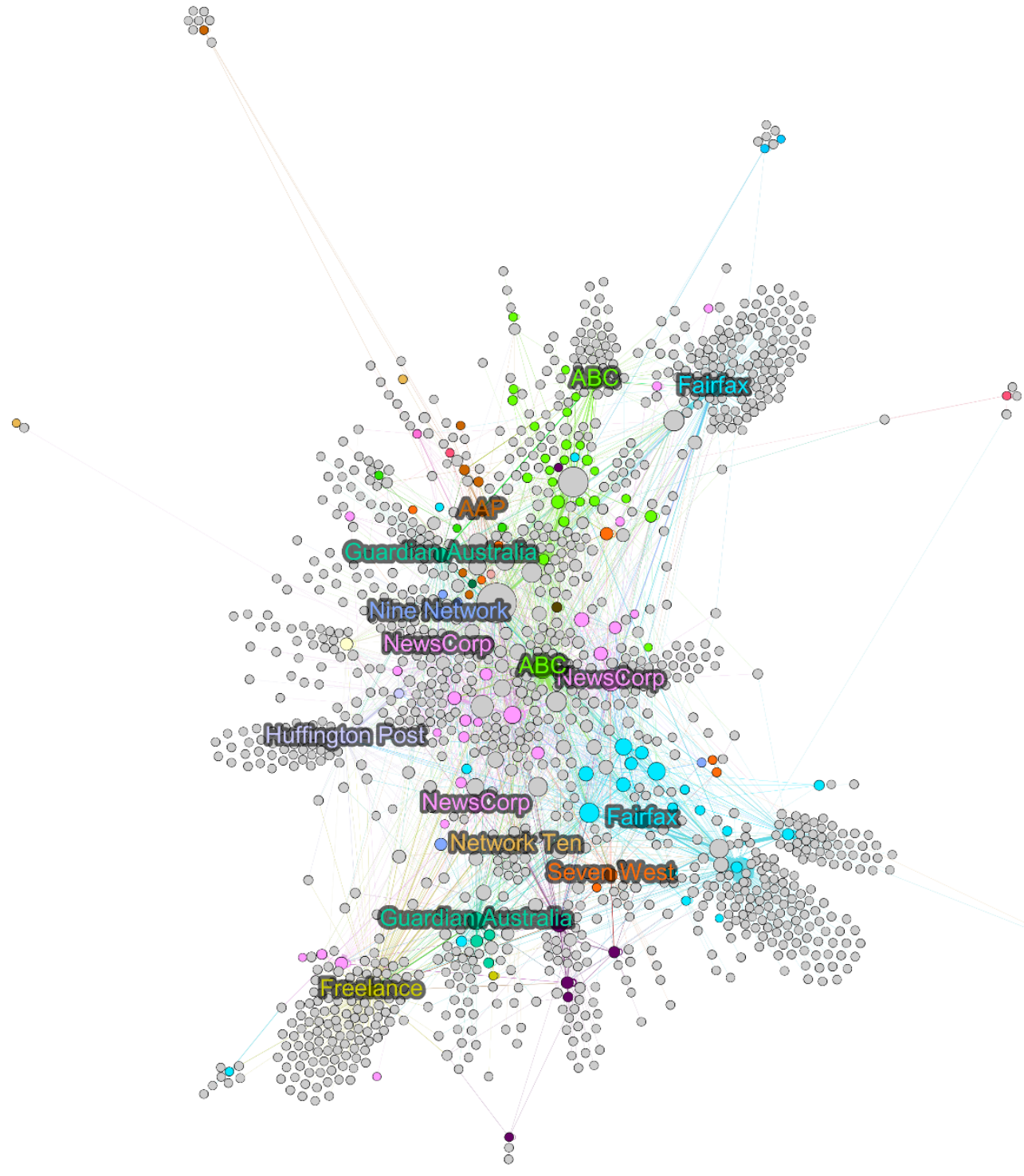

Figure 2. Press Gallery @mention network for accounts with degree >9 (2017). Network diameter: 6 (average geodesic distance: 3.129$)$. Network density: 0.002.

work is determined by whom the journalists themselves choose to @mention, and how consistently. Therefore, in Germany, where the platform - and social media more generally-remain less central to the news, this active core of the journalistic Twittersphere at the national parliament still focusses much more strongly on an elite group of interlocutors surrounding the journalists, especially at their own outlets. In Australia, by contrast, social media are now key platforms for news engagement, and the network map indicates that press corps journalists themselves also engage in somewhat broader networks, including with highly engaged but otherwise ordinary Twitter users. As journalists from various outlets engage through @mention conversations with such ordinary users, this would serve to pull together Press Gallery members into one network of elite political journalists that shows comparatively limited tendencies towards clustering and stratification.

\section{Conclusion}

Cross-country comparisons that systematically investigate social media engagement by journalists, and audience responses to it, over longer periods remain rare. Our year-long comparison between Germany and Australia examined key metrics and network structures for such engagement, and has documented some strongly divergent patterns of activity and engagement. It shows that Twitter has infiltrated the field of political journalism in Australia more comprehensively than in Germany.

There are many reasons for these developments, but we suggest that overall patterns of media use and news consumption in each system are particularly influential. In Germany, forms of traditional media use still dominate; additionally, the journalistic workforce is older on average than in Australia. Other structural factors are also likely to influence how journalists embrace and 
adapt to social media. Germany's journalistic culture is known to be comparatively shielded from market forces, and has been described as "more unitary and robust toward external influences" (Revers, 2017, p. 32). This may serve to slow Germany's adoption of new practices.

Our analysis has therefore confirmed the considerably different roles that Twitter plays as a platform for the sourcing, dissemination, and discussion of the news: while Australian press corps journalists are substantially more active, and also receive far more engagement from ordinary users in return, their German counterparts have proven considerably more reluctant to incorporate Twitter fully into their professional workflows.

Even so, in both countries the journalists' own conversational activities remain relatively elitist. On average, Australian press corps members tweet more, and also @mention a larger number of unique accounts-yet the range of accounts they @mention most frequently is, if anything, even more limited. In Germany, the Bundespressekonferenz members' inner circle comprises an elite of fellow journalists, news outlets, and politicians; journalists in the Australian Press Gallery communicate even more strongly amongst themselves, to the comparative exclusion even of political actors.

Although in both countries political journalists also interact with ordinary users, these occasional interactions appear important only in isolated cases. Future research should analyse the content of interactions between journalists and politicians, and between journalists and activists. Is there an "on-going discursive struggle" here (Ekman \& Widholm, 2015)? How and when do political journalists respond to attempts by non-elite actors to shape the news? The influence of network structuresthe extent to which relationships with journalists can be successfully activated-deserves particular attention in this context.

If the central core of conversations amongst political journalists remains relatively elitist, however, it nonetheless does not constitute a hermetically sealed bubble impenetrable to outside voices: though not as extensively as with their own peers, press corps members (especially in Australia) do also engage with a significant number of ordinary users. This is true particularly for the most actively tweeting journalists: Press Gallery members in the most active decile of Australian journalists sent an average of over 3,200@mentions to nearly 1,200 unique accounts during the year; their German counterparts managed somewhat less than half of these averages.

We regard this as strong evidence of the gradual but inexorable influence of social media logics on professional journalism: the more news audiences adopt social media as news channels, the more will political journalists feel obliged-out of an intrinsic motivation to inform, or an extrinsic need to retain readers - to serve their audience through such platforms. But doing so necessarily also means adapting to their principles and conventions: on Twitter, engaging with others (through @mentions) rather than merely posting original information or shar- ing on existing news (through retweets). From our one year of data, we are unable to assess the longitudinal dynamics of this potential power shift, but the comparative analysis across the Bundespressekonferenz and Federal Press Gallery shows that the transformation of relationships between journalists and news audiences through social media is strongly affected by domestic contexts.

Most likely there are at least two major forces at play. On the one hand, the diversity and resilience of professional journalism in a given country may act as a retardant of change, by enabling a conservative, risk-averse stance for news organisations. On the other, the market context-including especially overall social media takeup by news audiences-may create an incentive for individual journalists and news organisations to incorporate social media meaningfully into their newsroom practices. In Australia, therefore, we already see considerable advancement in the social-mediatisation of political journalism; in Germany, journalists and news organisations have so far sought to retain their power and independence to a rather greater extent. Any change to these forces has significant implications for the shifting power balance between political journalists and their audiences, especially as the authority of the masthead declines and individual journalists and news users encounter each other increasingly on the "uncommon ground" (Loosen \& Schmidt, 2016, p. 7) of social media platforms.

Finally, any such transformations are also likely to be affected by the nature of the newsbeat. Leading political correspondents are regularly presented as prominent representatives of their news outlets, and we argue that this prestige positions them as important role models for other journalists and the general public, able to influence their social media use. However, the subject matter of different newsbeats necessarily affects social media practices: business journalists may speak to and with a considerably more exclusive in-group of experts and analysts, while sports reporters might engage more readily with ordinary fans. Our research therefore also points to two key avenues for the further extension of the approach we have employed here: first, there is considerable opportunity for a comparison of our results with equivalent parliamentary press corps in other nations, and for a cross-national comparison of similar well-defined journalistic corps in other specialist fields; second, there is a need to systematically compare the social media practices of journalists across diverse newsbeats to examine how the newsroom staff across these beats adjust to the logic of social media in their activities. This will enable us to further distinguish the various factors that affect the dynamics of social media adoption and adaptation in journalism.

\section{Acknowledgments}

We thank Anna Diederichs for her support in verifying the journalists' Twitter accounts and her valuable com- 
ments on the draft article. This research was supported by the Australian Research Council Discovery project Journalism beyond the Crisis: Emerging Forms, Practices and Uses, and LIEF project TrISMA: Tracking Infrastructure for Social Media in Australia.

\section{References}

Albæk, E., van Dalen, A., Jebril, N., \& de Vreese, C. H. (2014). Political journalism in comparative perspective. New York, NY: Cambridge University Press.

Ausserhofer, J., \& Maireder, A. (2013). National politics on Twitter: Structures and topics of a networked public sphere. Information, Communication \& Society, 16(3), 291-314. doi:10.1080/ 1369118X.2012.756050

Bastian, M., Heymann, S., \& Jacomy, M. (2009). Gephi: An open source software for exploring and manipulating networks. In Proceedings of the third international ICWSM conference (pp. 361-362). San José: AAAI Press. Retrieved from http://www. aaai.org/ocs/index.php/ICWSM/09/paper/viewFile/ 154/1009

Borra, E., \& Rieder, B. (2014). Programmed method: Developing a toolset for capturing and analyzing tweets. Aslib Journal of Information Management, 66(3), 262-278. doi:10.1108/AJIM-09-2013-0094

Broersma, M., \& Graham, T. (2013). Twitter as a news source: How Dutch and British newspapers used tweets in their news coverage, 2007-2011. Journalism Practice, 7(4), 446-464. doi:10.1080/ 17512786.2013.802481

Brüggemann, M., Engesser, S., Büchel, F., Humprecht, E., \& Castro, L. (2014). Hallin and Mancini revisited: Four empirical types of Western media systems. Journal of Communication, 64(6), 1037-1065. doi:10.1111/jcom.12127

Bruno, N. (2011). Tweet first, verify later: How real-time information is changing the coverage. Oxford: Reuters Institute for the Study of Journalism. Retrieved from https://reutersinstitute.politics.ox.ac. uk/sites/default/files/Tweet\%20first\%20,\%20verify \%2Olater\%20How\%2Oreal-time\%20information\%20 is\%20changing\%20the\%20coverage $\% 20$ of $\% 2$ world wide\%20crisis\%20events.pdf

Bruns, A. (2018). Gatewatching and news curation: Journalism, social media, and the public sphere. New York, NY: Peter Lang.

Bruns, A., Nuernbergk, C., \& Schapals, A. K. (2018). What journalists share: A comparative study of the $\mathrm{Na}$ tional Press Corps in Australia and Germany. In A. Gruzd, J. Jacobson, P. Mai, R. Vatrapu, K. H. Kwon, J. Hemsley, A. Quan-Haase, ... \& \& J. Hodson (Eds.), Proceedings of the 9th international conference on social media and society (pp. 256-260). Copenhagen: ACM Press. doi:10.1145/3217804.3217924

Chadwick, A. (2013). The hybrid media system: Politics and power. New York, NY: Oxford University Press.
Ekman, M., \& Widholm, A. (2015). Politicians as media producers: Current trajectories in the relation between journalists and politicians in the age of social media. Journalism Practice, 9(1), 78-91. doi:10.1080/ 17512786.2014.928467

Hallin, D. C., \& Mancini, P. (2004). Comparing media systems: Three models of media and politics. Cambridge: Cambridge University Press.

Hanusch, F. (2013). Journalists in times of change: Evidence from a new survey of Australia's journalistic workforce. Australian Journalism Review, 35(1), 29-42.

Hanusch, F., \& Nölleke, D. (2018). Journalistic homophily on social media. Digital Journalism, 6(7), 1-23. doi:10.1080/21670811.2018.1436977

Hedman, U. (2016). When journalists tweet: Disclosure, participatory, and personal transparency. Social Media + Society, 2(1). doi:10.1177/2056305115624528

Hölig, S., \& Hasebrink, U. (2018). Reuters Institute digital news report 2018: Ergebnisse für Deutschland [Results for Germany]. Arbeitspapiere des Hans-BredowInstituts (No. 44). Hamburg: Hans-Bredow-Institut für Medienforschung. Retrieved from https://hansbredow-institut.de/uploads/media/Publikationen/ cms/media/t611qnd_44RDNR18_Deutschland.pdf

Jacomy, M., Venturini, T., Heymann, S., \& Bastian, M. (2014). ForceAtlas2, a continuous graph layout algorithm for handy network visualization designed for the Gephi software. PLOS ONE, 9(6), e98679. doi:10.1371/journal.pone.0098679

Jones, P., \& Pusey, M. (2010). Political communication and 'media system': The Australian canary. Media, Culture \& Society, 32(3), 451-471.

Loosen, W., \& Schmidt, J.-H. (2016). Between proximity and distance: Including the audience in journalism (research). Working Paper No. 14. Communicative Figurations. Bremen: University of Bremen. Retrieved from https://www.kommunikativefigurationen.de/fileadmin/user_upload/Arbeitspapie re/CoFi_EWP_No-14_Loosen_Schmidt.pdf

Molyneux, L., \& Holton, A. (2015). Branding (health) journalism: Perceptions, practices, and emerging norms. Digital Journalism, 3(2), 225-242. doi:10.1080/ 21670811.2014.906927

Neveu, E. (2002). Four generations of political journalism. In R. Kuhn \& E. Neveu (Eds.), Political journalism: New challenges, new practices (pp. 24-44). London: Routledge.

Newman, N., Fletcher, R., Kalogeropoulos, A., Levy, D. A. L., \& Nielsen, R. K. (2017). Reuters Institute digital news report 2017. Oxford: Reuters Institute for the Study of Journalism. Retrieved from https:// reutersinstitute.politics.ox.ac.uk/sites/default/files/ Digital\%20News\%20Report\%202017\%20web_0.pdf

Newman, N., Fletcher, R., Kalogeropoulos, A., Levy, D. A. L., \& Nielsen, R. K. (2018). Reuters Institute digital news report 2018. Oxford: Reuters Institute for the Study of Journalism. Retrieved from http://media. 
digitalnewsreport.org/wp-content/uploads/2018/06/ digital-news-report-2018.pdf?x89475

Nuernbergk, C. (2016). Political journalists' interaction networks: The German Federal Press Conference on Twitter. Journalism Practice, 10(7), 868-879. doi:10.1080/17512786.2016.1162669

Pariser, E. (2011). The filter bubble: What the Internet is hiding from you. London: Penguin.

Park, S., Fisher, C., Fuller, G., \& Lee, J. Y. (2018). Digital news report: Australia 2018. Canberra: News \& Media Research Centre, University of Canberra. Retrieved from http://apo.org.au/system/files/174861/ apo-nid174861-877051.pdf

Parmelee, J. H. (2014). The agenda-building function of political tweets. New Media \& Society, 16(3), 434-50. doi:10.1177/1461444813487955

Posetti, J. (2010, March 2). The \#spill effect: Twitter hashtag upends Australian political journalism. Mediashift. Retrieved from http://mediashift.org/ 2010/03/the-spill-effect-twitter-hashtag-upends-aus tralian-political-journalism061

Revers, M. (2017). Contemporary journalism in the US and Germany: Agents of accountability. New York, NY: Palgrave Macmillan.

Rogstad, I. D. (2014). Political news journalists in social media. Journalism Practice, 8(6), 688-703. doi:10.1080/17512786.2013.865965

Russell, F. M., Hendricks, M. A., Choi, H., \& Stephens, E. C. (2015). Who sets the news agenda on Twitter? Journalists' posts during the 2013 US government shutdown. Digital Journalism, 3(6), 925-943. doi:10.1080/21670811.2014.995918

Singer, J. B. (2005). The political j-blogger: "Normalizing" a new media form to fit old norms and practices. Journalism, 6(2), 173-198. doi:10.1177/
1464884905051009

Steindl, N., Lauerer, C., \& Hanitzsch, T. (2017). Journalismus in Deutschland [Journalism in Germany]. Publizistik, 62(3), 401-423. doi:10.1007/s11616-0170378-9

Tenore, M. J. (2010, December 9). Why The New York Times eliminated its social media editor position. Poynter. Retrieved from http://www.poynter.org/ 2010/why-the-new-york-times-eliminated-its-socialmedia-editor-position/110111

Thomaß, B., \& Horz, C. (2018). Germany-Media landscape. Maastricht: European Research Centre. Retrieved from https://medialandscapes.org/country/ pdf/germany

Vergeer, M. (2015). Peers and sources as social capital in the production of news: Online social networks as communities of journalists. Social Science Computer Review, 33(3), 277-297. doi:10.1177/ 0894439314539128

Verweij, P. (2012). Twitter links between politicians and journalists. Journalism Practice, 6(5/6), 680-691. doi:10.1080/17512786.2012.667272

Wright, S., Graham, T., \& Jackson, D. (2016). Third space, social media, and everyday political talk. In A. Bruns, G. Enli, E. Skogerb $\varnothing$, A. O. Larsson, \& C. Christensen (Eds.), The Routledge companion to social media and politics (pp. 74-88). New York, NY: Routledge.

Young, S. (2010). The journalism "crisis": Is Australia immune or just ahead of its time? Journalism Studies, 11(4), 610-624.

Zuiderveen Borgesius, F. J., Trilling, D., Möller, J., Bodó, B., de Vreese, C. H., \& Helberger, N. (2016). Should we worry about filter bubbles? Internet Policy Review, 5(1). doi:10.14763/2016.1.401

\section{About the Authors}

Axel Bruns is a Professor in the Digital Media Research Centre at Queensland University of Technology in Brisbane, Australia. His latest books are Gatewatching and News Curation: Journalism, Social Media, and the Public Sphere (2018) and Are Filter Bubbles Real? (2019). His current work focusses on the study of user participation in social media spaces such as Twitter, and its implications for our understanding of the contemporary public sphere. He serves as President of the Association of Internet Researchers.

Christian Nuernbergk (PhD, University of Münster) is Acting Professor of Media Studies and Communication at the University of Trier, Germany. His research fields include digital communication, political communication and (online) journalism. Nuernbergk is interested in the societal changes connected to the Internet and new media. In his current research, Nuernbergk uses network analysis in combination with surveys and content analysis to examine interactions in networked publics. He focusses on interactions between journalists, politicians, and citizens. 


\section{Appendix}

Table 1. Overall metrics for press corps journalists (2017).

\begin{tabular}{|c|c|c|c|}
\hline & \multicolumn{3}{|c|}{ BPK (Germany) } \\
\hline & All & Top decile (most active journalists) & Top decile (most followed jounalists) \\
\hline Number of tweets (sum) & 243,431 & 151,354 & 95,253 \\
\hline in $\%$ & $100 \%$ & $62 \%$ & $39 \%$ \\
\hline$M$ Tweets & 609 & 3,784 & 2,381 \\
\hline Md Tweets & 150 & 1,942 & 975 \\
\hline Number of active journalists & 400 & 40 & 40 \\
\hline$M$ Followers & 2,436 & 7,007 & 16,135 \\
\hline Md Followers & 633 & 3,333 & 8,722 \\
\hline$M$ Followees (friend count) & 525 & 1,198 & 1,112 \\
\hline Md Followees (friend count) & 328 & 938 & 944 \\
\hline \multirow[t]{3}{*}{ Number of verified accounts } & 55 & 10 & 19 \\
\hline & \multicolumn{3}{|c|}{ Press Gallery (Australia) } \\
\hline & All & Top decile (most active journalists) & Top decile (most followed jounalists) \\
\hline Number of tweets (sum) & 274,201 & 136,826 & 80,797 \\
\hline in $\%$ & $100 \%$ & $50 \%$ & $29 \%$ \\
\hline$M$ Tweets & 1,507 & 7,601 & 4,489 \\
\hline Md Tweets & 495 & 7,198 & 3,496 \\
\hline Number of active journalists & 182 & 18 & 18 \\
\hline$M$ Followers & 13,280 & 39,030 & 84,597 \\
\hline Md Followers & 3,483 & 15,597 & 92,835 \\
\hline$M$ Followees (friend count) & 1,793 & 4,040 & 2,320 \\
\hline Md Followees (friend count) & 1,240 & 3,164 & 1,515 \\
\hline Number of verified accounts & 115 & 14 & 17 \\
\hline
\end{tabular}


Table 2. Tweeting metrics for press corps journalists (2017).

\begin{tabular}{|c|c|c|c|c|}
\hline & \multicolumn{4}{|c|}{ Bundespressekonferenz (Germany) } \\
\hline & \multicolumn{2}{|c|}{ All journalists } & \multicolumn{2}{|c|}{ Top decile (most active journalists) } \\
\hline & Tweets & Unique accounts & Tweets & Unique accounts \\
\hline Total number of tweets (sum) & 243,431 & 28,871 & 151,354 & 20,645 \\
\hline in $\%$ & $100 \%$ & $100 \%$ & $62 \%$ & $71 \%$ \\
\hline Original tweets (sum) & 54,891 & - & 29,672 & - \\
\hline in $\%$ & $23 \%$ & - & $20 \%$ & - \\
\hline M Original tweets per sender & 167 & - & 797 & - \\
\hline Md Original tweets per sender & 51 & - & 540 & - \\
\hline Retweets (sum) & 110,552 & 16,198 & 68,667 & 12,068 \\
\hline in $\%$ & $45 \%$ & $56 \%$ & $45 \%$ & $58 \%$ \\
\hline$M$ Retweets per sender & 313 & 128 & 1,726 & 602 \\
\hline Md Retweets per sender & 91 & 44 & 954 & 447 \\
\hline @mentions (sum) & 112,474 & 20,319 & 70,020 & 14,704 \\
\hline in $\%$ & $46 \%$ & $70 \%$ & $46 \%$ & $71 \%$ \\
\hline$M @$ mentions per sender & 292 & 144 & 1,756 & 695 \\
\hline Md @mentions per sender & 60 & 49 & 958 & 475 \\
\hline & \multicolumn{4}{|c|}{ Press Gallery (Australia) } \\
\hline & \multicolumn{2}{|c|}{ All journalists } & \multicolumn{2}{|c|}{ Top decile (most active journalists) } \\
\hline & Tweets & Unique accounts & Tweets & Unique accounts \\
\hline Total number of tweets (sum) & 274,201 & 29,520 & 136,826 & 18,454 \\
\hline in \% & $100 \%$ & $100 \%$ & $50 \%$ & $63 \%$ \\
\hline Original tweets (sum) & 84,659 & - & 44,341 & - \\
\hline in $\%$ & $31 \%$ & - & $32 \%$ & - \\
\hline M Original tweets per sender & 498 & - & 2,377 & - \\
\hline Md Original tweets per sender & 147 & - & 1,784 & - \\
\hline Retweets (sum) & 100,823 & 15,207 & 48,049 & 10,598 \\
\hline in $\%$ & $37 \%$ & $52 \%$ & $35 \%$ & $57 \%$ \\
\hline$M$ Retweets per sender & 591 & 236 & 2,741 & 990 \\
\hline Md Retweets per sender & 196 & 107 & 2,720 & 914 \\
\hline @mentions (sum) & 117,091 & 20,702 & 57,386 & 12,601 \\
\hline in $\%$ & $43 \%$ & $70 \%$ & $42 \%$ & $68 \%$ \\
\hline$M @$ mentions per sender & 677 & 310 & 3,232 & 1,187 \\
\hline Md @mentions per sender & 222 & 145 & 3,057 & 1,173 \\
\hline
\end{tabular}

Note: As single tweets can contain both retweets and @mentions, metrics for tweet types can add up to move than $100 \%$. 
Table 3. Engagement metrics for press corps journalists (2017).

\begin{tabular}{|c|c|c|c|c|}
\hline & \multicolumn{4}{|c|}{ Bundespressekonferenz (Germany) } \\
\hline & \multicolumn{2}{|c|}{ All journalists } & \multicolumn{2}{|c|}{ Top decile (most active journalists) } \\
\hline & Tweets & Unique accounts & Tweets & Unique accounts \\
\hline Total mentions received & 714,206 & 116,790 & 423,150 & 73,464 \\
\hline in $\%$ & $100 \%$ & $100 \%$ & $59 \%$ & $63 \%$ \\
\hline Retweets received & 185,648 & 55,837 & 110,875 & 37,218 \\
\hline in \% & $26 \%$ & $48 \%$ & $26 \%$ & $51 \%$ \\
\hline$M$ retweets per journalist & 548 & 335 & 2,742 & 1,447 \\
\hline Md retweets per journalist & 74 & 47 & 1,032 & 683 \\
\hline @mentions received & 548,651 & 86,900 & 327,424 & 53,515 \\
\hline in \% & $77 \%$ & $74 \%$ & $77 \%$ & $73 \%$ \\
\hline \multirow{2}{*}{$\begin{array}{l}M @ \text { mentions per journalist } \\
M d @ \text { mentions per journalist }\end{array}$} & 1,411 & 583 & 8,512 & 2,675 \\
\hline & 224 & 141 & 4,072 & 1,757 \\
\hline & \multicolumn{4}{|c|}{ Press Gallery (Australia) } \\
\hline & \multicolumn{2}{|c|}{ All journalists } & \multicolumn{2}{|c|}{ Top decile (most active journalists) } \\
\hline & Tweets & Unique accounts & Tweets & Unique accounts \\
\hline Total mentions received & $1,904,700$ & 231,496 & 920,635 & 92,635 \\
\hline in $\%$ & $100 \%$ & $100 \%$ & $48 \%$ & $40 \%$ \\
\hline Retweets received & 450,495 & 83,851 & 276,292 & 59,345 \\
\hline in \% & $24 \%$ & $36 \%$ & $30 \%$ & $64 \%$ \\
\hline$M$ retweets per journalist & 2,750 & 1,285 & 15,562 & 5,928 \\
\hline Md retweets per journalist & 323 & 258 & 9,477 & 4,309 \\
\hline @mentions received & $1,429,061$ & 178,338 & 653,230 & 62,159 \\
\hline \multirow{2}{*}{$\begin{array}{l}\text { in \% } \\
M @ \text { mentions per journalist }\end{array}$} & $75 \%$ & $77 \%$ & $71 \%$ & $67 \%$ \\
\hline & 8,348 & 2,717 & 36,574 & 8,395 \\
\hline Md @mentions per journalist & 1,129 & 648 & 30,007 & 8,098 \\
\hline
\end{tabular}


Table 4. Interaction metrics (@mentions only) for press corps journalists (2017).

\begin{tabular}{|c|c|c|c|}
\hline & \multicolumn{3}{|c|}{ Bundespressekonferenz (Germany) } \\
\hline & All & $\begin{array}{c}\text { Top decile } \\
\text { (most active journalists) }\end{array}$ & $\begin{array}{c}\text { Top decile } \\
\text { (most followed jounalists) }\end{array}$ \\
\hline Total accounts@mentioned & 19,751 & 13,934 & 11,777 \\
\hline Other press corps members @mentioned & 331 & 262 & 216 \\
\hline Number of @mentioning journalists & 319 & 40 & 40 \\
\hline Total @mentions posted & 112,474 & 70,020 & 48,335 \\
\hline \multirow{4}{*}{$\begin{array}{l}\text { Number of @mentions of other } \\
\text { press corps members }\end{array}$} & 13,358 & 7,882 & 4,778 \\
\hline & $12 \%$ & $11 \%$ & $10 \%$ \\
\hline & \multicolumn{3}{|c|}{ Press Gallery (Australia) } \\
\hline & All & $\begin{array}{c}\text { Top decile } \\
\text { (most active journalists) }\end{array}$ & $\begin{array}{c}\text { Top decile } \\
\text { (most followed jounalists) }\end{array}$ \\
\hline Total accounts @mentioned & 20,702 & 12,601 & 8,333 \\
\hline Other press corps members@mentioned & 162 & 140 & 127 \\
\hline Number of @mentioning journalists & 162 & 18 & 18 \\
\hline Total @mentions posted & 117,091 & 57,836 & 32,454 \\
\hline Number of @mentions of other & 26,296 & 12,578 & 6,155 \\
\hline in \% & $22 \%$ & $22 \%$ & $19 \%$ \\
\hline
\end{tabular}

Table 5. Most @mentioned types of accounts (2017).

\begin{tabular}{|c|c|c|c|c|}
\hline & by Bundespressekonferenz accounts & in $\%$ & by Press Gallery accounts & in $\%$ \\
\hline Journalists (individual profiles) & 52 & $31 \%$ & 107 & $48 \%$ \\
\hline News organisations & 40 & $24 \%$ & 31 & $14 \%$ \\
\hline Political actors & 54 & $32 \%$ & 47 & $21 \%$ \\
\hline International accounts & 4 & $2 \%$ & 5 & $2 \%$ \\
\hline Other & 20 & $12 \%$ & 31 & $14 \%$ \\
\hline Total & 170 & $100 \%$ & $223^{*}$ & $100 \%$ \\
\hline
\end{tabular}

Notes: Accounts were only considered for analysis if mentioned by at least three different journalists with weight $>9$ during $2017 .{ }^{*}$ Two accounts were deleted and thus not classified. 